\title{
Diagnostic efficiency of serum IGF-I, IGF-binding protein-3 (IGFBP-3), IGF-I/IGFBP-3 molar ratio and urinary GH measurements in the diagnosis of adult GH deficiency: importance of an appropriate reference population
}

\author{
M L Granada ${ }^{1}$, J Murillo ${ }^{2}$, A Lucas ${ }^{2}$, I Salinas ${ }^{2}$, M A Llopis ${ }^{1}$, I Castells ${ }^{2}$, M Foz $^{3}$ and A Sanmartí ${ }^{2}$ \\ ${ }^{1}$ Departments of Clinical Biochemistry, ${ }^{2}$ Endocrinology and ${ }^{3}$ Internal Medicine, Hospital Universitari Germans Trias i Pujol, \\ Autonomous University of Barcelona, Badalona, Spain \\ (Correspondence should be addressed to M L Granada, Department of Clinical Biochemistry, Hospital Universitari Germans Trias i Pujol, \\ Crta.del Canyet s/n, 08916 Badalona, Spain; Email: mgranada@ns.hugtip.scs.es.)
}

\begin{abstract}
Objective: To analyse the diagnostic role of serum IGF-I, IGF-binding protein-3 (IGFBP-3), IGF-I/IGFBP-3 molar ratio and urinary GH (uGH) excretion in adult GH deficiency (GHD).

Design: Twenty-seven adults (age range: 18-71 years) with severe GHD, defined by a peak GH response to an insulin tolerance test below $3 \mu \mathrm{g} / \mathrm{l}$ in patients with at least one additional pituitary hypofunction. Reference values were established from a selected age- and body mass index-matched population (154 healthy adults grouped in four age groups).

Methods: IGF-I and IGFBP-3 were measured by RIA (Nichols) and results expressed as standard deviation (S.D.) scores from our reference population and assay normative data (s.D. score Nichols). uGH was measured by IRMA.

Results: Within the control group, IGF-I, IGFBP-3, IGF-I/IGFBP-3 ratio standardisation regarding our control population and IGF-I with respect to the assay normative data resulted in disappearance of agerelated differences. However, IGFBP-3 S.D. score Nichols resulted in mean values between +1.4 and +2.5 s.D. score. Greatest diagnostic efficiency was for IGF-I standardised with respect to our controls $(97.2 \%)$, followed by S.D. score IGFBP-3 $(92.9 \%)$. S.D. score IGF/IGFBP-3 ratio and uGH showed poor diagnostic efficiency. Any combination of at least two abnormal parameters raised specificity to $100 \%$. IGF-I standardised with respect to assay reference (s.D. score Nichols) showed similar diagnostic value (95.0\%) whereas IGFBP-3 showed low sensitivity (33.3\%). Within the GHD patients, those with three or more additional deficiencies had lower S.D. score IGF-I than those with only two or one.

Conclusion: We underline the importance of an appropriate reference population for correct interpretation of GH secretion markers. Considering our results, specificity obtained with two simultaneous abnormal parameters when referred to an adequate reference population may add valuable information to alternative GH stimulation tests to confirm adult GHD.
\end{abstract}

European Journal of Endocrinology 142 243-253

\section{Introduction}

Diagnosis of growth hormone (GH) deficiency (GHD) in adults is still a matter of debate. Assuming that no clinical feature can be relied on as a guide, the approach to diagnosis must include a high index of suspicion of hypothalamic-pituitary disease. At present, the insulin tolerance test (ITT) is the diagnostic tool of choice and severe GHD is defined by a peak GH response to hypoglycaemia of less than $3 \mu \mathrm{g} / \mathrm{l}$ (1), even though this test is contraindicated in patients with electrocardiographic evidence or history of ischaemic heart disease or in patients with seizure disorders, and there is less experience in patients over the age of 60. Other stimulation tests have proved their usefulness for GHD diagnosis but the maximum response for $\mathrm{GH}$ diagnosis has not been unanimously established in an adult population (2-4). Insulin-like growth factor-I (IGF-I) plus its most abundant circulating binding protein, IGFbinding protein-3 (IGFBP-3) (5), have been proposed as an initial screening procedure for suspected $\operatorname{GHD}(6,7)$, but the usefulness of these biochemical markers of GH action is controversial (8). Both are GH-regulated, but age- and nutrition-dependency often renders interpretation of results difficult, thus making it desirable for each laboratory to have its own normative data matched 
for age and body mass index (BMI). However, such data are not always available since their collection is expensive, time consuming and requires a high degree of collaboration between clinical and laboratory departments. Thus, it is common practice to make use of reference values provided by commercial assay manufacturers, which include values obtained in a group of control subjects, usually stratified by age and/or sex, but lacking any information on body fatness measurement. Altered body composition, with increased body weight and body fat mass and decreased lean body mass, is a clinical characteristic of GHD $(9,10)$ and should be taken into account in the matched reference population.

Recently, it has been argued that total IGF-I concentration, in analogy with thyroid and sex steroid hormones, may not reflect IGF bioactivity. Thus, measurement of the serum unbound IGF-I fraction (free IGF-I) might have greater physiological and clinical importance than its total concentration (11). The ratio on a molar basis between IGF-I and the predominant IGF binding protein (IGFBP-3) has been reported to correlate with free IGF-I (12) and has been proposed as an indirect measure of the easily dissociable circulating IGF-I (13).

Several authors have demonstrated that measurement of urinary $\mathrm{GH}(\mathrm{uGH})$ excretion reflects endogenous $\mathrm{GH}$ secretion $(14,15)$. The recently developed methods for $\mathrm{uGH}$ measurement with improved specificity and sensitivity provide a useful, reliable and non-invasive tool for assessing increased or decreased $\mathrm{GH}$ production $(16,17)$.

The present study was designed to analyse the diagnostic usefulness of serum IGF-I, IGFBP-3, serum IGF-I/IGFBP-3 molar ratio and uGH in the diagnosis of severe adult GHD, defined by a GH response to ITT below $3 \mu \mathrm{g} / \mathrm{l}$ in patients with at least one additional pituitary hypofunction. In a preliminary step, reference values for IGF-I, IGFBP-3, IGF-I/IGFBP-3 molar ratio and uGH were established from a selected adult population matched for BMI and divided into four age groups. The diagnostic efficiency of both IGF-I and IGFBP-3 standardised with respect to our own adult control population and to reference values provided by the kit manufacturer were calculated and compared.

\section{Patients and methods}

\section{Patients}

Twenty-seven GHD adults (17 females, 10 males), mean \pm S.D. age $47.4 \pm 16.3$ years (range 18-71 years) and mean \pm S.D. BMI $27.5 \pm 3.6 \mathrm{~kg} / \mathrm{m}^{2}$ (range $23.0-38.2 \mathrm{~kg} / \mathrm{m}^{2}$ ) were evaluated. GHD had been diagnosed by a peak $\mathrm{GH}$ response to insulin-induced hypoglycaemia test (ITT) below $3 \mu \mathrm{g} / \mathrm{l}$ (measured by a two-site chemiluminescence enzyme immunometric assay used with the DPC IMMULITE Automated Analyzer, Diagnostic Product Corporation, Los Angeles, CA, USA). All patients had at least one additional pituitary hormone deficit. The number of anterior pituitary hormone deficiencies excluding GH were: three deficiencies in 19, two in 3 and one in 5 patients. Twenty-six patients were hypogonadal, 22 were hypothyroid, 20 were hypoadrenal and 7 had anti-diuretic hormone deficiency. All patients received adequate replacement for their pituitary hormone deficiencies (except for GHD). The aetiologies of GHD and clinical characteristics of patients are shown in Table 1.

Three patients had childhood-onset GHD and three additional anterior pituitary hormone deficiencies. Their GHD was reassessed at the age of 18 years. None of them had received treatment with GH during the previous year.

All subjects gave their informed written consent according to the Helsinki Declaration. The study was approved by the ethics committee of our hospital.

\section{Control group}

One hundred and fifty-four adults (93 females, 61 males), mean \pm s.D. age $39.8 \pm 14.8$ (range $17.5-77$ years), mean BMI $25.7 \pm 4.8 \mathrm{~kg} / \mathrm{m}^{2}$ (range $18-39 \mathrm{~kg} / \mathrm{m}^{2}$ ) with stable body weight, comprising hospital employees and relatives, medical students and patients with benign thyroid pathology agreed to participate as controls. None had any acute or chronic disease that could affect the GH-IGF-I axis. They were divided into four groups according to age: group I: below 25 years; group II: between 25.0 and 39.9 years; group III: between 40.0 and 54.9 years; and group IV: over 55 years.

\section{Blood sampling and urine collection}

Serum IGF-I and IGFBP-3 were determined from a basal blood sample obtained from all subjects in the morning after an overnight fast. Blood samples drawn into plain tubes from an antecubital vein were centrifuged and the serum separated and kept frozen until assayed. In addition, one (in 90 out of 154 control adults) or three (in all GHD patients) separate $24 \mathrm{~h}$ urine samples were collected and kept at $4^{\circ} \mathrm{C}$. Total volume was recorded and $30 \mu \mathrm{l} 300 \mathrm{~g} / \mathrm{l} \mathrm{BSA}$ were added to $5 \mathrm{ml}$ aliquots of each sample before freezing at $-80^{\circ} \mathrm{C}$.

\section{Laboratory methods}

Serum IGF-I was measured by RIA after separation of the binding proteins by acid-ethanol precipitation (Nichols Institute Diagnostics, San Juan Capistrano, CA, USA). The assay was calibrated against International Reference Preparation IRP 87/518. Interassay coefficients of variation (CVs) ranged from 5.2 to $8.4 \%$. The detection limit of the assay was $13.5 \mathrm{ng} / \mathrm{ml}$. IGFBP-3 was measured with an RIA (Nichols Institute Diagnostics). Interassay CVs ranged from 5.7 to $6.5 \%$. uGH was measured using an IRMA with a $\mathrm{CV}<8.1 \%$ and a detection limit of $0.5 \mathrm{ng} / \mathrm{l}\left({ }^{125} \mathrm{I}-\mathrm{hGH} \mathrm{U}\right.$ COATRIA, BioMérieux, Marcy L’Etoile, France). 
Table 1 Characteristics of patients with GHD.

\begin{tabular}{|c|c|c|c|c|c|c|c|c|c|c|c|c|}
\hline Patient & $\begin{array}{c}\text { Age } \\
\text { (years) }\end{array}$ & Sex & $\begin{array}{c}\mathrm{BMI} \\
\left(\mathrm{kg} / \mathrm{m}^{2}\right)\end{array}$ & $\begin{array}{c}\text { Cause of } \\
\text { hypopituitarism }\end{array}$ & $\begin{array}{l}\text { No. of } \\
\text { axes }\end{array}$ & $\begin{array}{l}\text { IGF-I } \\
(\mathrm{ng} / \mathrm{ml})\end{array}$ & $\begin{array}{c}\text { IGF-I } \\
\text { (s.D. Score) }\end{array}$ & $\begin{array}{c}\text { IGFBP-3 } \\
(\mu \mathrm{g} / \mathrm{ml})\end{array}$ & $\begin{array}{l}\text { IGFBP-3 } \\
\text { (s.D. score) }\end{array}$ & $\begin{array}{c}\text { Ratio } \\
\text { (IGF-I/IGFBP-3) }\end{array}$ & $\begin{array}{c}\text { Ratio } \\
\text { (s.D. score) }\end{array}$ & $\begin{array}{c}\text { uGH } \\
(\mathrm{ng} / 24 \mathrm{~h})\end{array}$ \\
\hline 1 & 41 & $\mathrm{~F}$ & 23.1 & Non-secretory adenoma & 2 & 59.7 & -3.3 & 2.10 & -2.0 & 0.11 & -2.6 & 5.44 \\
\hline 2 & 44 & M & 29.0 & Non-secretory adenoma & 1 & 69.3 & -2.8 & 1.80 & -2.8 & 0.16 & -1.6 & 0.70 \\
\hline 3 & 49 & M & 28.3 & Non-secretory adenoma & 3 & 69.3 & -2.9 & 2.00 & -2.2 & 0.14 & -1.9 & 0.30 \\
\hline 4 & 52 & $\mathrm{~F}$ & 26.0 & Non-secretory adenoma & $3+D I$ & 48.1 & -3.9 & 2.25 & -1.6 & 0.08 & -3.5 & 0.54 \\
\hline 5 & 58 & M & 29.8 & Non-secretory adenoma & 3 & 105.8 & -1.5 & 1.55 & -4.2 & 0.28 & +1.0 & 0.30 \\
\hline 6 & 58 & M & 27.1 & Non-secretory adenoma & 1 & 75.0 & -2.9 & 2.35 & -1.7 & 0.13 & -1.8 & 0.22 \\
\hline 7 & 63 & M & 26.3 & Non-secretory adenoma & $3+\mathrm{DI}$ & 75.0 & -2.9 & 1.28 & -5.3 & 0.24 & +0.4 & 1.39 \\
\hline 8 & 63 & M & 25.0 & Non-secretory adenoma & 1 & 132.8 & -0.6 & 1.70 & -3.6 & 0.32 & +1.5 & 1.44 \\
\hline 9 & 68 & M & 26.6 & Non-secretory adenoma & 1 & 67.3 & -3.3 & 1.20 & -5.7 & 0.18 & +0.3 & 0.80 \\
\hline 10 & 30 & $\mathrm{~F}$ & 28.8 & Sheehan's syndrome & 3 & 55.8 & -4.1 & 2.45 & -8.2 & 0.09 & -3.6 & 0.30 \\
\hline 11 & 42 & $\mathrm{~F}$ & 38.2 & Sheehan's syndrome & 3 & 38.5 & -4.6 & 2.31 & -1.5 & 0.06 & -4.4 & 0.78 \\
\hline 12 & 50 & $\mathrm{~F}$ & 28.8 & Sheehan's syndrome & 3 & 32.7 & -5.0 & 1.70 & -3.1 & 0.08 & -3.9 & 0.30 \\
\hline 13 & 50 & $\mathrm{~F}$ & 23.1 & Sheehan's syndrome & 3 & 38.5 & -4.6 & 0.84 & -6.8 & 0.18 & -1.0 & 0.30 \\
\hline 14 & 18 & $\mathrm{~F}$ & 25.3 & Craniopharyngioma & $3+\mathrm{DI}$ & 50.0 & -8.3 & 0.88 & -6.8 & 0.23 & -1.8 & 0.98 \\
\hline 15 & 18 & M & 24.3 & Craniopharyngioma & $3+\mathrm{DI}$ & 138.6 & -3.9 & 1.75 & -3.5 & 0.32 & -0.6 & 1.00 \\
\hline 16 & 22 & $\mathrm{~F}$ & 25.6 & Craniopharyngioma & $3+\mathrm{DI}$ & 159.7 & -3.3 & 2.90 & -1.1 & 0.22 & -1.9 & 1.50 \\
\hline 17 & 47 & $\mathrm{~F}$ & 33.7 & Craniopharyngioma & $3+\mathrm{DI}$ & 132.8 & -0.9 & 2.74 & -0.6 & 0.20 & -0.8 & 0.30 \\
\hline 18 & 25 & $\mathrm{~F}$ & 25.8 & Other CNS tumors & 3 & 38.5 & -9.4 & 0.87 & -9.0 & 0.16 & -1.5 & 1.10 \\
\hline 19 & 55 & M & 27.4 & Other CNS tumors & 3 & 26.9 & -6.8 & 1.21 & -5.6 & 0.09 & -3.1 & 0.30 \\
\hline 20 & 68 & $\mathrm{~F}$ & 26.9 & Other CNS tumors & 2 & 88.5 & -2.2 & 2.50 & -1.4 & 0.14 & -1.4 & 1.80 \\
\hline 21 & 19 & $\mathrm{~F}$ & 23.0 & Empty sella & 3 & 55.8 & -7.8 & 1.00 & -6.2 & 0.23 & -1.8 & 0.30 \\
\hline 22 & 54 & M & 29.2 & Empty sella & 3 & 25.0 & -5.8 & 0.55 & -8.9 & 0.18 & -1.0 & 0.30 \\
\hline 23 & 60 & $\mathrm{~F}$ & 26.3 & Empty sella & 3 & 19.2 & -8.1 & 1.10 & -6.2 & 0.07 & -4.0 & 0.10 \\
\hline 24 & 48 & $\mathrm{~F}$ & 33.7 & Idiopathic hypopituitarism & 1 & 50.0 & -3.9 & 1.53 & -3.6 & 0.13 & -2.2 & 0.64 \\
\hline 25 & 71 & $\mathrm{~F}$ & 23.3 & Idiopathic hypopituitarism & 3 & 67.3 & -3.3 & 2.32 & -1.8 & 0.12 & -2.1 & 0.95 \\
\hline 26 & 67 & $\mathrm{~F}$ & 27.5 & Cushing's disease & 2 & 77.0 & -2.8 & 2.20 & -2.1 & 0.14 & -1.5 & 0.30 \\
\hline 27 & 39 & $\mathrm{~F}$ & 31.1 & Histiocytosis $\times$ CNS & $3+D I$ & 125.1 & -1.1 & 2.70 & -0.7 & 0.19 & -1.0 & 1.90 \\
\hline
\end{tabular}

$\mathrm{DI}=$ diabetes insipidus 


\section{Calculations and statistical analyses}

BMI was calculated by dividing weight by height ${ }^{2}\left(\mathrm{~kg} / \mathrm{m}^{2}\right)$.

The average of the three $24 \mathrm{~h} \mathrm{uGH}$ measurements was determined for each GHD patient and considered for subsequent analyses.

Molar IGF-I/IGFBP-3 ratio was calculated using $7.5 \mathrm{kDa}$ (IGF-I) and $30.5 \mathrm{kDa}$ (IGFBP-3) molecular masses respectively, as in previous reports $(12,13)$.

To approximate normal distributions, serum IGF-I and IGFBP-3 concentrations, IGF-I/IGFBP-3 molar ratio values and uGH were natural $\log (\mathrm{ln})$ transformed and used in all calculations. The number of standard deviation scores (s.D. score) from the age-related reference population mean was calculated for each value: S.D. score $=(\ln$ value - mean of the $\ln$ values $) /$ s.D. of the $\ln$ values). IGF-I and IGFBP-3 data were also expressed as S.D. score for age compared with normative data provided by the kit manufacturer (s.D. score Nichols). Simple linear regression analysis ( $r$ value) was performed to test the associations between variables. Multivariate analysis tested the independent associations of different variables. Groups were compared by means of one-way ANOVA and the multiple comparison test of Scheffé. The cut-off limit for IGF-I, IGFBP-3, IGF-I/IGFBP-3 ratio and uGH excretion was set at -2 s.D. score. As the selected cut-off point for $\mathrm{uGH}$ in reference groups over 25 years of age overlapped with the detection limit of the method
$(0.5 \mathrm{ng} / \mathrm{l})$ (17), this value was used instead of -2 s.D. score in these age groups. Sensitivity of the parameters was defined as the percentage of GHD patients with a value below the selected cut-off criterion. Specificity was defined as the percentage of control subjects with a value above the selected cut-off limit. Efficiency was defined as the number of GHD patients with a subnormal value plus the number of controls with a normal value divided by total number of subjects studied (GHD patients and controls). Predictive value of positive test (PPV) was defined as the percentage of values below the cut-off limit that represent GHD. Predictive value of negative test (NPV) was defined as percentage of values above the cutoff criterion represented by controls. Data were expressed as means \pm S.D., and geometric means \pm 2 s.D. ln backtransformed range. $P<0.05$ was considered statistically significant.

\section{Results}

\section{Control group}

Table 2 shows characteristics and hormone values (mean and -2 s.D. score to +2 s.D. score range) of the control population divided into four groups according to age. BMI differed significantly by ANOVA among the four age groups; it was significantly lower in those

Table 2 Characteristics and hormonal values (mean and 2 S.D. range) of the reference population divided into four age groups.

\begin{tabular}{|c|c|c|c|c|}
\hline Age & $<25$ years & $25-40$ years & $40-55$ years & $>55$ years \\
\hline$n$ & 26 & 50 & 52 & 26 \\
\hline $\operatorname{Sex}(M / F)$ & $12 / 14$ & $19 / 31$ & $19 / 33$ & $11 / 15$ \\
\hline $\mathrm{BMI}^{*}\left(\mathrm{~kg} / \mathrm{m}^{2}\right)$ & $22.6 \pm 4.4^{\mathrm{a}}$ & $24.3 \pm 4.0^{b}$ & $27.7 \pm 4.4$ & $27.5 \pm 4.1$ \\
\hline $\begin{array}{l}\mathrm{IGF}^{*} \mathrm{I}^{* *} \\
(\mathrm{ng} / \mathrm{ml})\end{array}$ & $\begin{array}{c}338.0^{c} \\
(212-538)\end{array}$ & $\begin{array}{c}227.0^{\mathrm{d}} \\
(114-452)\end{array}$ & $\begin{array}{c}184.4 \\
(96.2-353)\end{array}$ & $\begin{array}{c}162.8 \\
(92.8-285.4)\end{array}$ \\
\hline $\begin{array}{l}\text { IGF-I } \\
\text { (S.D. score controls) }\end{array}$ & $\begin{array}{c}-0.03 \\
(-2.03 \text { to }+2.03)\end{array}$ & $\begin{array}{c}+0.01 \\
(-2.00 \text { to }+2.03)\end{array}$ & $\begin{array}{c}+0.01 \\
(-1.90 \text { to }+1.91)\end{array}$ & $\begin{array}{c}+0.15 \\
(-2.02 \text { to }+2.30)\end{array}$ \\
\hline $\begin{array}{l}\text { IGF-I } \\
\text { (S.D. score Nichols) }\end{array}$ & $\begin{array}{c}-0.29 \\
(-0.99 \text { to }+0.99)\end{array}$ & $\begin{array}{c}-0.10 \\
(-1.98 \text { to }+1.78)\end{array}$ & $\begin{array}{c}+0.07 \\
(-1.84 \text { to }+1.98)\end{array}$ & $\begin{array}{c}+0.36 \\
(-1.60 \text { to }+2.30)\end{array}$ \\
\hline $\begin{array}{l}\text { IGFBP-3** } \\
(\mu \mathrm{g} / \mathrm{ml})\end{array}$ & $\begin{array}{c}3.62^{\mathrm{e}} \\
(2.39-5.47)\end{array}$ & $\begin{array}{c}3.27 \\
(2.38-4.50)\end{array}$ & $\begin{array}{c}3.0 \\
(2.01-4.45)\end{array}$ & $\begin{array}{c}3.17 \\
(2.27-4.43)\end{array}$ \\
\hline $\begin{array}{l}\text { IGFBP-3 } \\
\text { (s.D. score controls) }\end{array}$ & $\begin{array}{c}-0.08 \\
(-2.04 \text { to }+1.88)\end{array}$ & $\begin{array}{c}-0.01 \\
(-1.97 \text { to }+1.95)\end{array}$ & $\begin{array}{c}-0.15 \\
(-2.19 \text { to }+1.89)\end{array}$ & $\begin{array}{c}+0.01 \\
(-1.95 \text { to }+1.97)\end{array}$ \\
\hline $\begin{array}{l}\text { IGFBP-3 } \\
\text { (s.D. score Nichols) }\end{array}$ & $\begin{array}{c}+1.63 \\
(+0.17 \text { to }+3.09)\end{array}$ & $\begin{array}{c}+1.4 \\
(+0.06 \text { to }+2.74)\end{array}$ & $\begin{array}{c}+2.49^{f} \\
(+0.13 \text { to }+4.85)\end{array}$ & $\begin{array}{c}+2.56^{f} \\
(-0.24 \text { to }+5.36)\end{array}$ \\
\hline $\begin{array}{l}\text { IGF-I/IGFBP-3 } \\
\text { ratio }\end{array}$ & $\begin{array}{c}0.38^{c} \\
(0.22-0.66)\end{array}$ & $\begin{array}{c}0.28 \\
(0.15-0.54)\end{array}$ & $\begin{array}{c}0.25 \\
(0.14-0.46)\end{array}$ & $\begin{array}{c}0.21 \\
(0.12-0.37)\end{array}$ \\
\hline $\begin{array}{l}\text { IGF-I/IGFBP-3 } \\
\text { ratio (S.D. score controls) }\end{array}$ & $\begin{array}{c}0.00 \\
(-2.00 \text { to }+2.00)\end{array}$ & $\begin{array}{c}0.00 \\
(-2.00 \text { to }+2.00)\end{array}$ & $\begin{array}{c}0.00 \\
(-1.99 \text { to }+1.99)\end{array}$ & $\begin{array}{c}0.00 \\
(-2.00 \text { to }+2.00)\end{array}$ \\
\hline $\begin{array}{l}u_{G H}^{* *} \\
(n g / 24 h)\end{array}$ & $\begin{array}{c}7.3^{\mathrm{g}} \\
(2.1-24.7)\end{array}$ & $\begin{array}{c}3.3 \\
(<0.5-24.5)\end{array}$ & $\begin{array}{c}2.1 \\
(<0.5-27.9)\end{array}$ & $\begin{array}{c}2.8 \\
(<0.5-46.0)\end{array}$ \\
\hline
\end{tabular}

*Mean \pm S.D.

${ }^{* *}$ Geometric mean (in back-transformed mean).

a Significantly lower than group age: $40-55$ and >55 years; ${ }^{b}$ significantly lower than group age: $40-55$ years; ${ }^{\mathrm{C}}$ significantly higher than group age: $25-40,40-55$ and $>55$ years; ${ }^{d}$ significantly higher than group age: $40-55$ and $>55$ years; ${ }^{\text {e }}$ significantly higher than group age $>55$ years; ${ }^{\dagger}$ significantly higher than group age: $<25$ and $25-40$ years; ${ }^{9}$ significantly higher than group age: $40-55$ years. 
Table 3 Multiple regression analysis for age and BMI against In-transformed IGF-I, IGFBP3, IGF-I/IGFBP-3 molar ratio and $\mathrm{UGH}$.

\begin{tabular}{ccc}
\hline & $\beta$ & $\boldsymbol{P}$ \\
\hline In IGF-I & & \\
Age & -0.57 & $<0.0001$ \\
BMI & -0.05 & 0.50 \\
In IGFBP-3 & & \\
Age & -0.27 & 0.025 \\
BMI & -0.04 & 0.65 \\
In ratio & & \\
Age & -0.49 & $<0.0001$ \\
BMI & -0.04 & 0.59 \\
In uGH & & \\
Age & -0.04 & 0.69 \\
BMI & -0.32 & 0.010 \\
\hline
\end{tabular}

under 25 years than in those over 40 years, and was significantly lower in the group from 25.0 to 39.9 years than in those from 40.0 to 54.9 years.

Serum IGF-I concentrations significantly declined with advancing age, whereas IGFBP-3, IGF-I/IGFBP-3 ratio, and $\mathrm{uGH}$ were significantly higher only in the younger group. Multiple regression analysis (Table 3) showed that age was a significant negative determinant of changes in IGF-I, IGFBP-3 and IGF-I/IGFBP-3 ratio, while these parameters were uninfluenced by the introduction of BMI. Conversely, changes in uGH were explained by changes in BMI and not by age.

IGF-I values standardised with respect to the assay's normative data (s.D. score Nichols) led to disappearance of age-related differences, as occurred when our own reference values were used. However, IGFBP-3 standardised with respect to the assay's age-reference values (S.D. score Nichols) resulted in mean S.D. score values between +1.4 and +2.5 , and was significantly higher in the two groups over the age of 40 than in those under 40 (Table 2).

\section{GHD patients}

Table 1 shows clinical characteristics and hormone parameters evaluated in each patient. Hormone data were expressed as absolute concentrations and standardised with respect to our control population. Patients were divided into two groups according to the number of additional pituitary deficiencies presented: three or less than three. Standardised IGF-I was significantly lower in patients with three additional pituitary deficiencies $(n=19)$ than in those with one or two $(n=8)$ : S.D. score controls: $-4.4 \pm 2.2$ vs $-2.7 \pm 1.0$, $P=0.01$; S.D. score Nichols: $-3.6 \pm 1.7$ vs $-2.1 \pm 1.1$, $P=0.017)$. Standardised IGFBP-3 was lower in patients with three additional pituitary deficiencies than in those with one or two, but the difference was not statistically significant: S.D. score controls: $-4.5 \pm 3.1$ vs $-2.8 \pm 1.4$,
$P=0.07$; s.D. score Nichols: $-1.7 \pm 2.5$ vs $-0.5 \pm 1.4$, $P=0.12$. No differences were found in standardised IGF-I/IGFBP-3 ratio or uGH between the two groups.

\section{Characteristics and hormone data in GHD and controls}

No differences were found in the proportion of males and females between GHD patients (37.0 and 62.9\%) and controls (39.6 and 60.4\%).

Although mean BMI in GHD patients $(27.4 \pm 3.6 \mathrm{~kg} /$ $\left.\mathrm{m}^{2}\right)$ was slightly higher than in controls $(25.7 \pm 4.8 \mathrm{~kg} /$ $\mathrm{m}^{2}$ ), the difference was not statistically significant.

Figure 1 shows IGF-I and IGFBP-3 in patients and controls standardised with respect to our control population (S.D. score controls). Figure 2 shows IGF-I and IGFBP-3 in patients and controls standardised with respect to the assay's age-reference values (S.D. score Nichols). Figure $2 b$ reflects the inadequacy of the assay's age-reference values in patients and controls, especially those over the age of 40. Standardised IGF-I/IGFBP-3 ratio and $\mathrm{uGH}$ excretion in GHD patients and controls are depicted in Figs 3 and 4.

\section{Diagnostic usefulness of hormone parameters}

Table 4 shows the diagnostic value of all parameters evaluated. IGF-I values standardised with respect to our reference population showed the best diagnostic efficiency $(97.2 \%)$, followed by S.D. score IGFBP-3 $(92.9 \%)$. Despite its high specificity $(99.3 \%)$, s.D. score IGF/IGFBP-3 ratio showed poorer diagnostic efficiency due to low sensitivity $(37 \%)$, whereas uGH had lower diagnostic efficiency $(83.6 \%)$ due to lower specificity. Any combination of at least two abnormal parameters yielded sensitivity of $77.7 \%$ but raised specificity to $100 \%$. When age-reference values provided by the assay manufacturer (S.D. score Nichols) were used to standardise IGF-I and IGFBP-3, IGF-I showed lower sensitivity $(70.4 \%)$ but similar diagnostic value (95.0\%). However, IGFBP-3 showed very low sensitivity (33.3\%) together with $100 \%$ specificity; few GHD patients and none of the controls were below -2 s.D. score, but $53.8 \%$ of the controls older than 40 years had IGFBP-3 over +2 s.D. score (Fig. 2 b).

\section{Discussion}

Demonstration of the beneficial effects of GH treatment in adults with suspected GHD in $1989(18,19)$ raised the need to identify GHD status in adulthood. The lack of specificity of the clinical syndrome, the physiological decrease in $\mathrm{GH}$ with ageing and the reduced $\mathrm{GH}$ secretion associated with increased adiposity make it difficult to establish clear-cut biochemical criteria to distinguish patients with hyposomatotropism from healthy elderly individuals (20-23). Although initial 

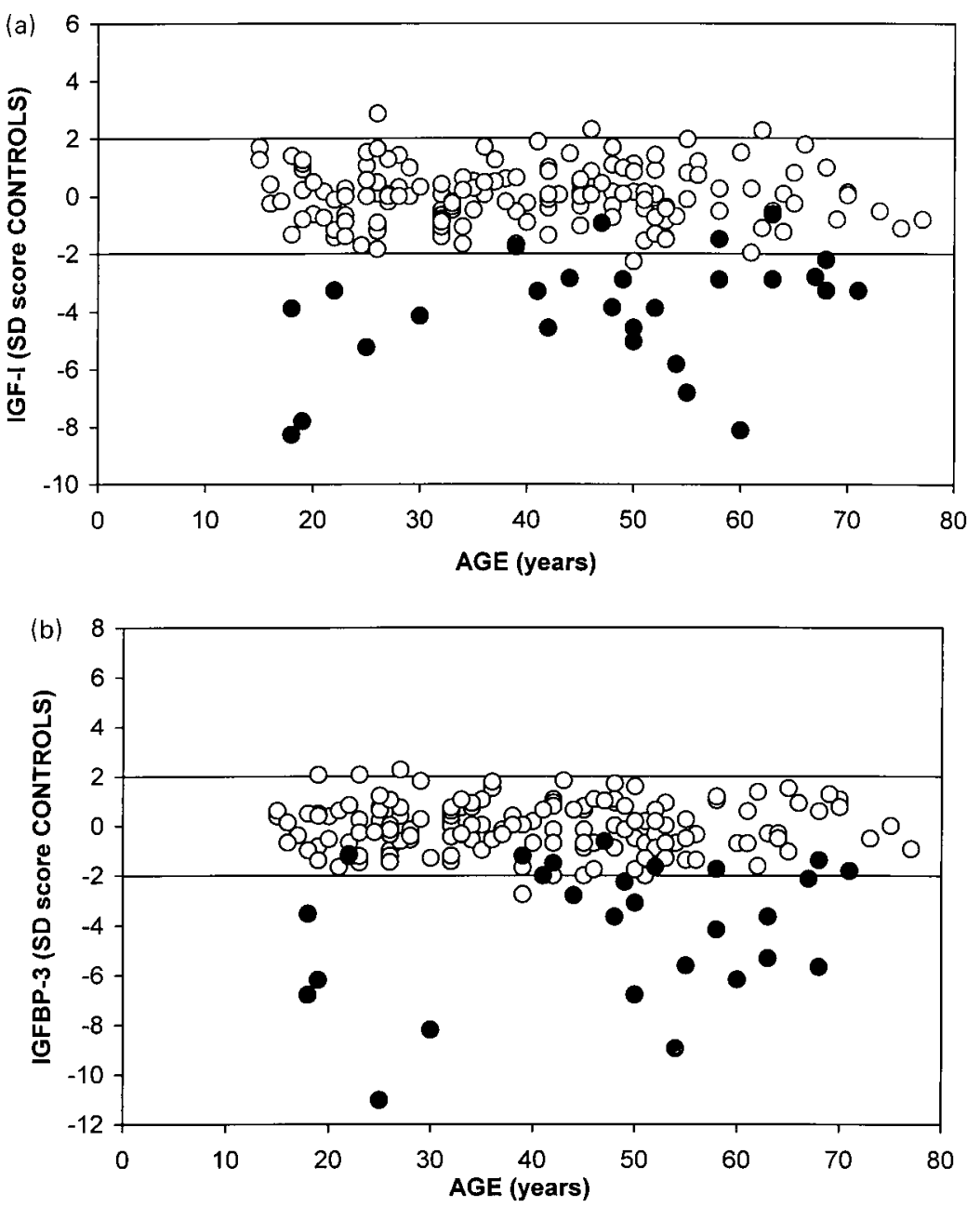

Figure 1 Serum IGF-I (a) and IGFBP-3 (b) concentrations expressed as S.D. Score with respect to our reference population (S.D. Score controls) in GHD patients $(\bullet)$ and controls $(O)$ plotted vs age. reports on adults with GHD had applied different arbitrary criteria for selection of GHD patients $(9,18$, $19,24)$, a first consensus statement for the diagnosis of adult GHD was formulated in 1994 (25) and reviewed and updated in 1997 by the Growth Hormone Research Society in a workshop held in Port Stephens (1). At present, criteria for profound GHD are met if peak GH response to an ITT with symptomatic hypoglycaemia is below $3 \mu \mathrm{g} / \mathrm{l}$, and thus this was the biochemical selection criterion chosen for patients included in our study. Although it would be desirable for each laboratory to establish its own GH cut-off level rather than simply accept those recommended in the literature (26), it is almost impossible for most endocrine centres to perform $\mathrm{GH}$ provocative tests in a large number of healthy subjects. Moreover, the recommended diagnostic test has some drawbacks: it has a high intraindividual day-to-day variation in healthy adults (27), harbours a certain risk for the patient, being expressly contraindicated in some (1), and lower GH responses are to be expected in obese subjects $(28,29)$. Other stimulation tests are mandatory when ITT is contraindicated (1). The reported usefulness of some alternative tests, especially those combining GH-releasing hormone with arginine or pyridostigmine, for adult GHD diagnosis makes them eligible for gold standard status in the future $(4,30-32)$. However, the search for biochemical markers of integrated GH action in adults should not be abandoned, particularly as published data on their diagnostic usefulness are contradictory. Some investigators have demonstrated high diagnostic efficiency for measurements of serum IGF-I (6, 33), IGFBP-3 (6) or uGH (34) in adult GHD diagnosis, whereas others have almost precluded their use $(8,35,36)$. Differences in GHD inclusion criteria and the lack of an adequate reference group might account for the discrepancies. Among studies including only severe GHD patients (peak GH below $3 \mu \mathrm{g} / \mathrm{l}$ ), the poorer diagnostic usefulness of IGF-I and IGFBP-3 has been reported by Hoffman et al. (8) and Roelen et al. (36) (sensitivities for IGF-I and IGFBP-3 of 30 and $28 \%$, and 27.7 and $44.4 \%$ respectively). Both studies compared IGF-I and IGFBP-3 in GHD patients (age spans of 61 years and 40 years respectively) with those obtained in a matched control group (35 subjects 

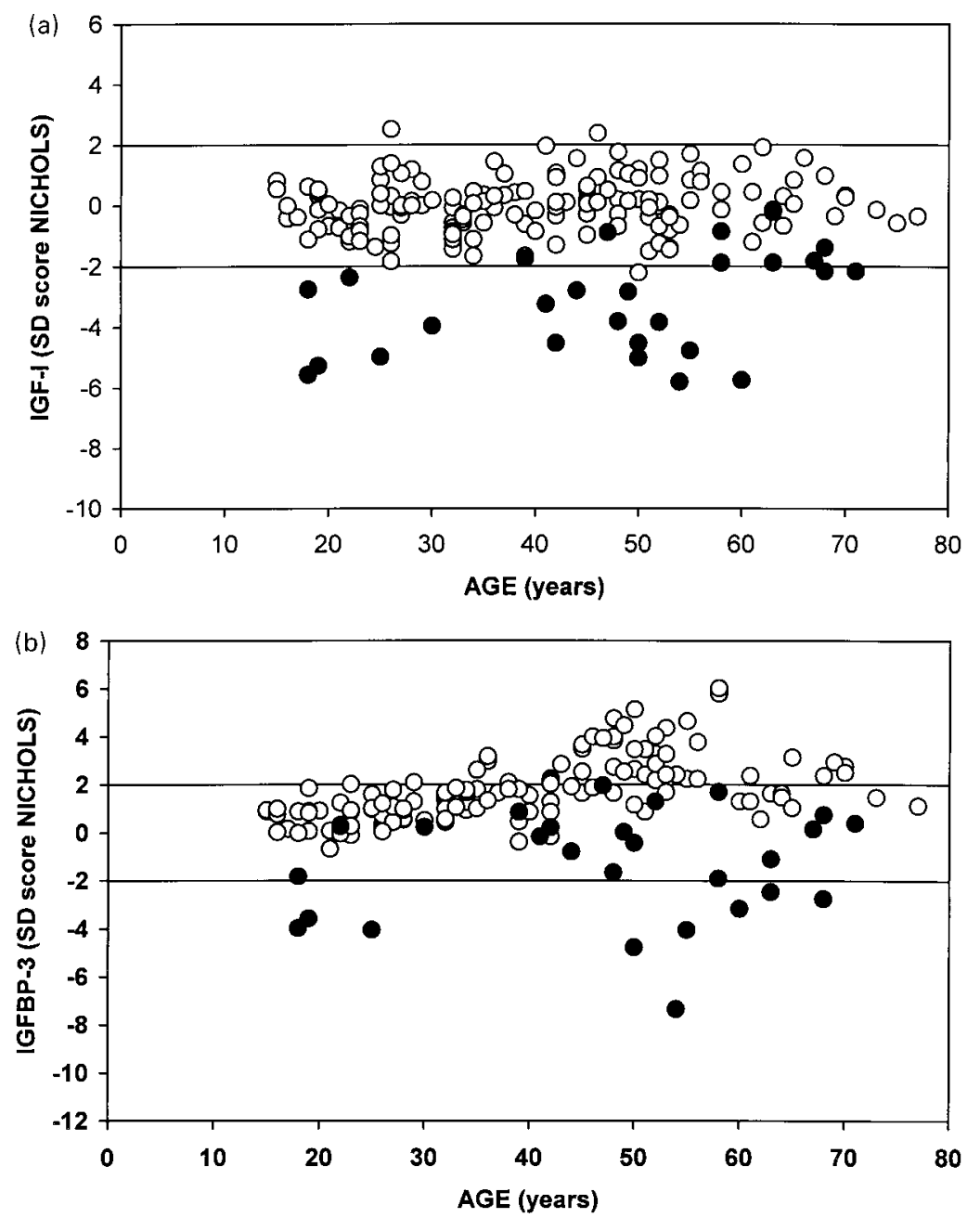

Figure 2 Serum IGF-I (a) and IGFBP-3 (b) concentrations expressed as S.D. Score with respect to the assay reference values (S.D. Score Nichols) in GHD patients (๑) and controls $(O)$ plotted vs age.

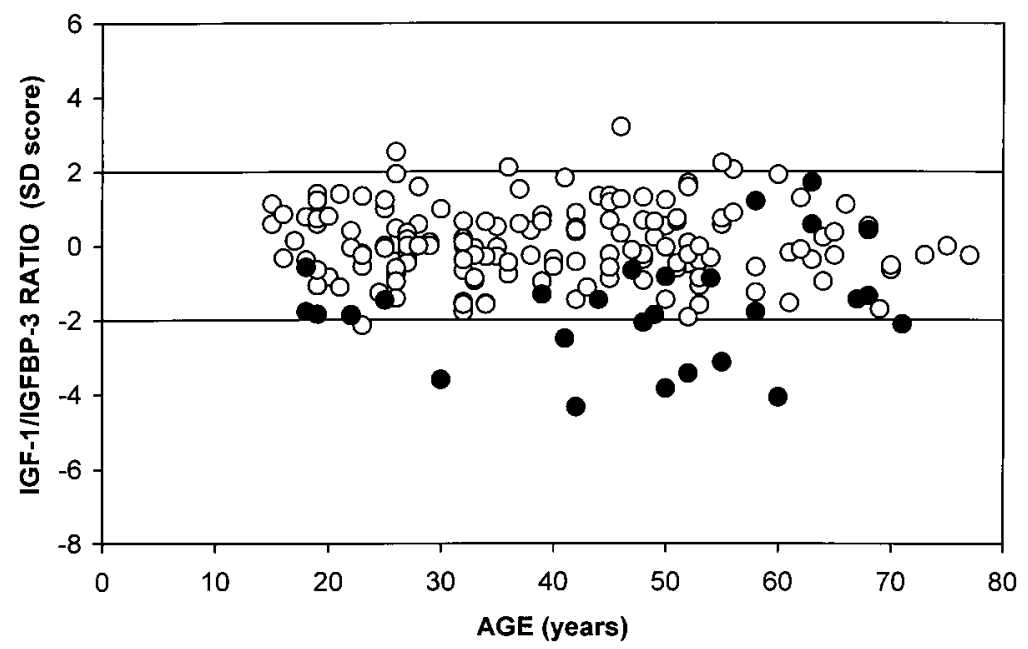

Figure 3 Serum IGF-I/IGFBP-3 molar ratio expressed as S.D. score with respect to our reference population (s.D. score controls) in GHD patients $(\bullet)$ and controls $(O)$ plotted vs age. 


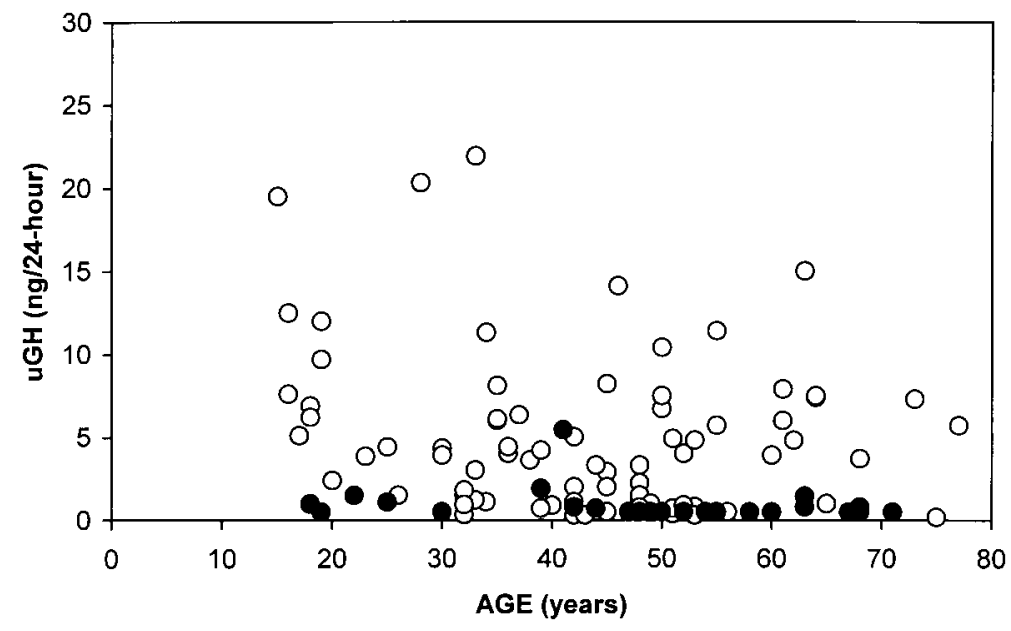

Figure $4 \mathrm{uGH}$ excretion expressed as $\mathrm{ng} / 24 \mathrm{~h}$ in GHD patients $(\bullet)$ and controls $(O)$ plotted vs age. from 17 to 77 years and 21 subjects from 25 to 55 years respectively); however, owing to the age-dependency of these growth factors, the $95 \%$ confidence interval range obtained in controls was too wide and resulted in lower sensitivity for the test especially for IGF-I, which declines steeply with age. In our study, if we had assessed IGF-I and IGFBP-3 diagnostic usefulness in GHD diagnosis with respect to the mean \pm 2 S.D. range obtained in the whole control group regardless of age (17-77 years), only 7 out of 27 for IGF-I (sensitivity: $25.9 \%$ ) and 15 out of 27 for IGFBP-3 (sensitivity: 55.6\%) would have been below the control range. However, when several narrower age range groups including sufficient numbers of subjects are used, and every patient is compared with the normal range of his or her age-matched group, better sensitivity is obtained $(85.2 \%$ for IGF-I and $70.4 \%$ for IGFBP-3) in accordance with data reported by others. Baum et al. (30) found significantly lower IGF-I and IGFBP-3 serum concentrations in 23 severely GHD patients than in 17 controls; however, only 39\% had IGF-I levels below the age-appropriate normal ranges provided by the assay manufacturer. The interesting study by Attanasio et al. (37) reports data from 173 adult patients who had GHD arising either in childhood or adulthood. Even though IGF-I and IGFBP-3 results were not standardised according to age, they found that IGF-I levels in GHD patients were below the normal adult reference range in both groups, while IGFBP-3 levels were below only in those with childhood onset.

The importance of an appropriate control population was noted when, before a sufficient number of control subjects had been collected, our IGF-I and IGFBP-3 results were standardised according to the normative data provided by the kit manufacturer (s.D. score Nichols). The cut-off point less than -2 s.D.score showed very low diagnostic sensitivity for IGFBP-3. However, when IGF-I and IGFBP-3 were analysed in a sufficient number of control subjects to perform our own age- and BMI-matched reference group, we realised that IGF-I concentrations in our control population fitted into the reference range, whereas IGFBP-3 values, particularly of subjects over 40 years, were above the normal range. Our reference values for IGFBP-3 in healthy adults over 30 years are not different from those reported by Juul et al. (13) from a healthy Danish population between 30 and 75 years $(n=198)$, which makes the existence of ethnic-based differences in serum IGFBP-3 concentrations unlikely.

Table 4 Diagnostic value for adult GHD of IGF-I and IGFBP-3 standardised with respect to our control population (s.D. score controls) and to the assay reference values (s.D. score Nichols). IGF-I/IGFBP-3 molar ratio standardised with respect to our control population and uGH in $\mathrm{ng} / 24 \mathrm{~h}$. The cut-off criterion was set at -2.0 s.D. score below the mean.

\begin{tabular}{lccccr}
\hline & $\begin{array}{c}\text { Sensitivity } \\
(\%)\end{array}$ & $\begin{array}{c}\text { Specificity } \\
(\%)\end{array}$ & $\begin{array}{c}\text { Diagnostic } \\
\text { efficiency } \\
(\%)\end{array}$ & $\begin{array}{c}\text { PPV } \\
(\%)\end{array}$ & $\begin{array}{c}\text { NPV } \\
(\%)\end{array}$ \\
\hline IGF-I (S.D. Score controls) & 85.2 & 99.3 & 97.2 & 95.8 & 97.4 \\
IGF-I (S.D. Score Nichols) & 70.4 & 99.3 & 95.0 & 95.0 & 95.0 \\
IGFBP-3 (S.D. Score controls) & 70.4 & 96.7 & 92.9 & 79.2 & 94.9 \\
IGFBP-3 (S.D. Score Nichols) & 33.3 & 100 & 90.0 & 100 & 89.5 \\
IGF-I/IGFBP-3 ratio (S.D. Score) & 37.0 & 99.3 & 89.9 & 90.9 & 89.8 \\
uGH (ng/24h) & 66.7 & 88.8 & 83.6 & 64.3 & 89.8 \\
\hline
\end{tabular}


The severity of GHD is largely related to the degree of hypopituitarism; Toogood et al. (38) reported that $90.3 \%$ of GHD patients with two or three additional deficiencies had a peak GH response to ITT below 5 $\mathrm{mU} / \mathrm{l}$, and a significant inverse relationship has been reported between IGF-I and the number of additional deficiencies $(6,39)$. In our study, despite all GHD patients having a peak $\mathrm{GH}$ response below $3 \mathrm{ng} / \mathrm{ml}$, those with three additional deficiencies had significantly lower IGF-I than those with only one or two.

IGF-I/IGFBP-3 molar ratio in controls significantly declined with age, in agreement with others $(12,30$, 40). Moreover, in our study this ratio was significantly diminished in GHD patients compared with their agematched controls, as previously reported (40). However, the diagnostic usefulness was very low and offered no advantage to measurement of serum IGF-I and IGFBP-3 (12) as it fell within the range observed in the agematched controls in $63 \%$ of our adult GHD patients. GHD is also associated with changes in other circulating IGFBPs $(12,30,40)$; thus, further studies including measurements of serum IGFBP-1 and IGFBP-2 are required for conclusions on the readily available IGF-I fraction to be drawn.

BMI in our control adult population increased with advancing age, thereby reflecting the age-related weight gain in the normal adult population $(41,42)$. However, no relationship was found between BMI and IGF-I, IGFBP-3 or their ratio when age was accounted for in multivariate analyses, in agreement with others (4244). Thus matching for BMI in a normal weight or mildly overweight population appears not to be essential for these parameters. This underscores the value of these biochemical markers in GHD diagnosis in comparison with measures of $\mathrm{GH}$ secretion, which inversely correlates with adiposity (20). The GH response to an acute provocative test is also negatively related to adiposity $(28,45)$. In our study, endogenous $\mathrm{GH}$ secretion was assessed by measuring $24 \mathrm{~h} \mathrm{GH}$ excretion (14-16). Within the control group, the higher $\mathrm{uGH}$ observed in the younger group was significantly explained by the lower BMI in that group, and not by age, thus supporting the negative relationship between GH secretion and adiposity. Mean uGH in the oldest control group was not significantly decreased, as expected by the age-related decrease in serum $\mathrm{GH}$ markers, which might be explained by impaired renal tubular reabsorption described in healthy elderly subjects (46). Thus, uGH was a worse diagnostic parameter of GHD in adulthood than serum IGF-I and IGFBP-3, probably due to its relationship with body fat, high intraindividual and interindividual variations in $\mathrm{GH}$ excretion, insufficient detection limit of the method and impaired tubular renal function in the elderly. Despite the increased sensitivity of specific uGH commercial IRMA assays, we were unable to set the lower limit of normalcy in age groups over 25 years, as it fell below the detection limit of the method. The diagnostic usefulness of uGH in severe adult GHD diagnosis found in our study is similar to that of previous reports (34) although we were unable to find differences in uGH according to the number of pituitary deficiencies.

In conclusion, this study underlines the importance of an appropriate reference population for the correct interpretation of GH secretion markers. In view of our results and those of other authors, in cases where ITT is contraindicated the low values obtained in two simultaneous GH secretion markers when referred to an adequate reference population may add valuable information to alternative $\mathrm{GH}$ stimulation tests to confirm adult GHD.

\section{Acknowledgements}

The authors thank Christine O'Hara for reviewing the English manuscript, and Pilar Ortiz and Ana Vega for their excellent technical assistance.

\section{References}

1 Growth Hormone Research Society. Consensus guidelines for the diagnosis and treatment of adults with growth hormone deficiency: summary statement of the Growth Hormone Research Society workshop on adult growth hormone deficiency. Journal of Clinical Endocrinology and Metabolism 199883 379-381.

2 Rahim A, Toogood AA \& Shalet SM. The assessment of growth hormone status in normal young males using a variety of provocative agents. Clinical Endocrinology 199645 557-562.

3 Vierhapper H, Nowotny P, Czech T, Bieglmayer C, Raber W \& Waldhäusl W. How (not) to diagnose growth hormone deficiency in adults: stimulated serum concentrations of growth hormone in healthy subjects and in patients with pituitary macroadenomas. Metabolism 199746 680-683.

4 Aimaretti G, Corneli G, Razzore P, Bellone S, Baffoni C, Arvat E et al. Comparison between insulin-induced hypoglycaemia and growth hormone (GH)-releasing hormone + arginine as provocative tests for the diagnosis of GH deficiency in adults. Journal of Clinical Endocrinology and Metabolism 199883 1615-1618.

5 Blum WF, Ranke MB, Kietzmann K, Gauggel E, Zeisel HJ \& Bierich JR. A specific radioimmunoassay for the growth hormone (GH)dependent somatomedin-binding protein: its use for diagnosis of GH deficiency. Journal of Clinical Endocrinology and Metabolism $1990701292-1298$.

6 Juul A, Kastrup KW, Pedersen SA \& Skakkebaek NE. Growth hormone $(\mathrm{GH})$ provocative retesting of 108 young adults with childhood-onset GH deficiency and the diagnostic value of insulin-like growth factor I (IGF-I) and IGF-binding protein-3. Journal of Clinical Endocrinology and Metabolism 199782 11951201.

7 De Boer H, Blok GJ \& Van der Veen EA. Clinical aspects of growth hormone deficiency in adults. Endocrine Reviews 199516 63-86.

8 Hoffman DM, O'Sullivan AJ, Baxter RC \& Ho KKY. Diagnosis of growth-hormone deficiency in adults. Lancet $19943431064-$ 1068.

9 Cuneo RC, Salomon F, McGauley GA \& Sönksen PH. The growth hormone deficiency syndrome in adults. Clinical Endocrinology 199237 387-397.

10 De Boer H, Blok GJ, Voerman HJ, De Vries PMJM \& Van der Veen EA. Body composition in adult growth hormone deficient men, assessed by anthropometry and bioimpedance analysis. Journal of Clinical Endocrinology and Metabolism 199275 833-837.

11 Frystyk J, Skjaerbaek C, Dinesen B \& Orskov H. Free insulin-like growth factors (IGF-I and IGF-II) in human serum. FEBS Letters $1994348185-191$. 
12 Skjaerbaek C, Vahl N, Frystyk J, Hansen TB, Jorgensen JOL, Hagen $\mathrm{C}$ et al. Serum free insulin-like growth factor-I in growth hormone-deficient adults before and after growth hormone replacement. European Journal of Endocrinology 1997137132 137.

13 Juul A, Main K, Blum WK, Lindholn J, Ranke MB \& Skakkebaek EN. The ratio between serum levels of insulin-like growth factor (IGF)-I and IGF binding proteins (IGFBP-1, -2, and -3) decreases with age in healthy adults and is increased in acromegalic patients. Clinical Endocrinology 199441 85-93.

14 Granada ML, Sanmartí A, Lucas A, Salinas I, Cuatrecasas JM, Foz $\mathrm{M}$ et al. Clinical usefulness of urinary growth hormone measurements in normal and short children according to different expressions of urinary growth hormone data. Pediatric Research $19923273-76$.

15 Girard J, Erb T, Pampalone A, Eberle AN \& Baumann JB. Growth hormone in urine: development of an ultrasensitive assay applicable to plasma and urine. Hormone Research 198728 71-80.

16 Main K, Philips M, Jorgensen M \& Skakkebak EN. Urinary growth hormone excretion in 657 healthy children and adults: norma values, inter- and intraindividual variations. Hormone Research 199136 174-182.

17 Porquet D, Leger J, Reverchon C, Louis S \& Passagot J. Dosage de l'hormone de croissance dans les urines. Etablissement des valeurs usuelles chez l'enfant à l'aide d'une trousse commerciale. Immunoanalyse et Biologie Spéccialisé 199337 1-6.

18 Salomon F, Cuneo RC, Hesp RC \& Sönksen PH. The effects of treatment with recombinant human growth hormone on body composition and metabolism in adults with growth hormone deficiency. New England Journal of Medicine $19893211797-$ 1803.

19 Jorgensen JOL, Pedersen SA, Thuesen L, Jorgensen J, IngemannHansen T, Skakkebaek NE et al. Beneficial effects of growth hormone treatment in GH-deficient adults. Lancet 1989 i 1221 1225.

20 Ho KY, Evans WS, Blizzard RM, Veldhuis JD, Merrian GR, Samojlik E et al. Effects of sex and age on the 24-h profile of growth hormone secretion in man: importance of endogenous estradio concentrations. Journal of Clinical Endocrinology and Metabolism $19876451-58$

21 Iranmanesh A, Lizarralde G \& Veldhuis JD. Age and relative adiposity are specific negative determinants of the frequency and amplitude of growth hormone $(\mathrm{GH})$ secretory bursts and the halflife of endogenous GH in healthy men. Journal of Clinical Endocrinology and Metabolism 199173 1081-1088.

22 Veldhuis JD, Iranmanesh A, Ho KKY, Waters NJ, Johnson NL \& Lizarralde G. Dual effects in pulsatile growth hormone secretion and clearance subserve the hyposomatotropism of obesity in man. Journal of Clinical Endocrinology and Metabolism 199172 51-59.

23 Rudman D, Kutner MH, Rogers MH, Lubin CM, Fleming GA \& Bain RT. Impaired growth hormone secretion in the adult population. Journal of Clinical Investigation 198167 1361-1369.

24 Whitehead HM, Aiken AB, Lewis S, Sheridan B \& Hadden DR. Physiological growth hormone secretion in adult growth hormone deficiency: comparison with normal controls. Clinical Endocrinology 199134 371-376.

25 Thorner MO, Bengtsson BA, Ho KY, Albertsson-Wikland K, Christiansen JF, Faglia G et al. The diagnosis of growth hormone deficiency (GHD) in adults. Journal of Clinical Endocrinology and Metabolism 199580 3097-3098.

26 Shalet SM, Toogood A, Rahim A \& Brennan BMD. The diagnosis of growth hormone deficiency in children and adults. Endocrine Reviews 199819 203-223.

27 Hoeck HC, Vestergaard P, Jakobsen PE \& Laurberg P. Tests of growth hormone secretion in adults: poor reproducibility of the insulin tolerance test. European Journal of Endocrinology 1995133 305-312.

28 Kopelman PG, Noonan K, Goulton R \& Forest KJ. Impaired growth hormone response to growth hormone releasing factor and insulin-induced hypoglycaemia in obesity. Clinical Endocrinology $19852387-94$.

29 Cordido F, Dieguez C \& Casanueva FF. Effect of central cholinergic neurotransmission enhancement by pyridostigmine on the growth hormone secretion elicited by clonidine, arginine, or hypoglycaemia in normal and obese subjects. Journal of Clinical Endocrinology and Metabolism 199070 1361-1370.

30 Baum HBA, Biller BMK, Katznelson L, Oppenheim DS, Clemmons DR, Cannistraro $\mathrm{KB}$ et al. Assessment of growth hormone $(\mathrm{GH})$ secretion in men with adult-onset GH deficiency compared with that in normal men - a clinical research centre study. Journal of Clinical Endocrinology and Metabolism 199681 84-92.

31 Andersen M, Hansen TB \& Stoving RK. The pyridostigminegrowth hormone-releasing-hormone test in adults. The reference interval and a comparison with the insulin tolerance test. Endocrinology and Metabolism 19963 197-206.

32 Ghigo E, Aimaretti G, Gianotti L, Bellone J, Arvar E \& Camanni F. New approach to the diagnosis of growth hormone deficiency in adults. European Journal of Endocrinology 1996134 352356.

33 De Boer H, Blok GJ, Popp-Snijders C \& Van der Veen EA. Diagnosis of growth hormone deficiency in adults (letter). Lancet 1994343 1645-1646.

34 Bates AS, Evans AJ, Jones P \& Clayton RN. Assessment of GH status in adults with GH deficiency using serum growth hormone, serum insulin-like growth factor-I and urinary growth hormone excretion. Clinical Endocrinology 199542 425-430.

35 Ho KKY \& Hoffman DM. Defining growth hormone deficiency in adults. Metabolism 199544 91-96.

36 Roelen CA, Koppeschaar HP, de Vries WR, Zelissen PM, Snel YE, Doerga ME et al. High-affinity growth hormone binding protein, insulin-like growth factor-I and insulin-like growth factor binding protein 3 in adults with growth hormone deficiency. European Journal of Endocrinology $199613582-86$.

37 Attanasio AF, Lamberts SWJ, Matranga AMC, Bitkett MA, Bates PC, Valk NK et al. Adult growth hormone deficient patients demonstrate heterogeneity between childhood onset and adult onset before and during human GH treatment. Journal of Clinical Endocrinology and Metabolism 199782 82-88.

38 Toogood AA, Beardwell CG \& Shalet SM. The severity of growth hormone deficiency in adults with pituitary disease is related to the degree of hypopituitarism. Clinical Endocrinology 199441 511-516.

39 Svensson J, Johannsson G \& Bengtsson BA. Insulin-like growth factor-I in growth hormone-deficient adults: relationship to population-based normal values, body composition and insulin tolerance test. Clinical Endocrinology $199746579-$ 586.

40 Jorgensen JOL, Vahl N, Hansen TB, Skjaerbaek C, Fisker S, Orsov $\mathrm{H}$ et al. Determinants of serum insulin-like growth factor I in growth hormone deficient adults as compared with healthy subjects. Clinical Endocrinology 199848 479-486.

41 Ricart W. González-Huix F \& Conde V. Valoración del estado de nutrición a través de los parámetros antropométricos: nuevas tablas en la población laboral de Cataluña. Medicina Clínica 1993 100 681-691.

42 Landin-Whilhelmsen K, Whilhelmsen L, Lappas G, Rosen T, Lindstedt G, Lundberg PA et al. Serum insulin-like growth factor I in a random population sample of men and women: relation to age, sex, smoking habits, coffee consumption and physical activity, blood pressure and concentrations of plasma lipids, fibrinogen, parathyroid hormone and osteocalcin. Clinical Endocrinology $199441351-357$.

43 Benbassat CA. Maki KC \& Unterman TG. Circulating levels of insulin-like growth factor (IGF) binding protein-1 and -3 in ageing men: relationships to insulin, glucose, IGF, and dehydroepiandrosterone sulphate levels and anthropometric measures. Journal of Clinical Endocrinology and Metabolism 1997 70 1292-1298. 
44 Nyström FH, Öhman PK, Ekman BA, Österlund MK, Karlberg BE \& arnqvist HJ. Population-based reference values for IGF-I and IGFbinding protein-1: relations with metabolic and anthropometric variables. European Journal of Endocrinology 1997136 165-172.

45 Williams T, Berelowitz M, Joffe SN, Thorner MO, Rivier J, Vale $\mathrm{W}$ et al. Impaired growth hormone responses to growth hormone-releasing factor in obesity. New England Journal of Medicine 1984311 1403-1407.
46 Sohmiya M \& Kato Y. Renal clearance, metabolic clearance rate, and half-life of human growth hormone in young and aged subjects. Journal of Clinical Endocrinology and Metabolism 199275 1487-1490.

Received 13 May 1999

Accepted 21 October 1999 